JUURNAL

of Health Inequalities

\title{
Profiles of patients qualified for bariatric surgeries with Roux-en-Y gastric bypass and sleeve gastrectomy methods
}

\author{
Natalia Komorniak', Małgorzata Szczuko', Monika Hoffmann'1, Bartosz Kowalewski², Krzysztof Kaseja \\ 'Department of Human Nutrition and Metabolomics, Pomeranian Medical University in Szczecin, Poland \\ ${ }^{2}$ Independent Provincial Public Hospital Complex in Szczecin-Zdunowo, Poland \\ IIndependent Public Clinical Hospital No. 2 Pomeranian Medical University in Szczecin, Poland
}

\begin{abstract}
Introduction: Bariatric surgery is one of the methods of extreme obesity treatment used in case of patients with body mass index (BMI) $\geq 40 \mathrm{~kg} / \mathrm{m}^{2}$ or $\mathrm{BMI} \geq 35 \mathrm{~kg} / \mathrm{m}^{2}$ and accompanying diseases (e.g. hypertension) for whom previous conservative treatment was not successful.

Aim of the study: To determine the anthropometric and biochemical profiles of patients qualified for Roux-en-Y gastric bypass (RYGB) or sleeve gastrectomy (SG).

Material and methods: The study involved 60 patients qualified for surgical treatment. The standardized Food Frequency Questionnaire supplemented by a survey which contained questions on previous attempts to lose weight and their results (including yo-yo effect) were administered. The anthropometric measurements included weight, height, waist and hip circumference. Biochemical analysis of blood (lipid profile, liver profile, glucose, glycated haemoglobin and C-reactive protein) were performed using calorimetric method. All the results were statistically analysed using the STATISTICA 12 software.

Results: The patients had a history of numerous attempts $(\geq 6)$ to lose weight using unbalanced diets. Women qualified for SG had higher levels of parameters indicating the presence of inflammatory state, dyslipidaemia and improper glycaemia. Men qualified for RYGB had significantly higher values of $\gamma$-glutamyl transpeptidase.

Conclusions: Numerous unsuccessful attempts to lose weight can signify a low level of nutritional knowledge and the need to educate the patients both before and after the surgery. Patients at higher perioperative risk (due to anthropometric and biochemical parameters) were qualified to less invasive surgery treatment. Higher risk of developing cholelithiasis after the surgery would be attributed to irrational attempts of body weight loss before the procedure, and not to the RYGB itself.
\end{abstract}

KEY WORDS: bariatric surgery, obesity, diet, cholestasis, dyslipidemias.

ADDRESS FOR CORRESPONDENCE: Małgorzata Szczuko, Department of Human Nutrition and Metabolomics, Pomeranian Medical University in Szczecin, 24 Broniewskiego St., 71-460 Szczecin, Poland, e-mail: malgorzata.szczuko@pum.edu.pl

\section{INTRODUCTION}

Obesity is a problem which has affected humanity for centuries. In the past it was sometimes considered a sign of prosperity, wealth and high social class. However, with the development and progress of civilization obesity became increasingly common and threatening to population health, and is regarded as an epidemic of the $20^{\text {th }}$ and $21^{\text {st }}$ centuries $[1,2]$. Bariatric surgery has been recognized as the most effective treatment of pathological obesity, with a high percentage of weight reduction and a relatively small number of complications. Currently, the most frequent bariatric procedures are sleeve gastrectomy (SG) and Roux-en-Y gastric bypass (RYGB) [3]. SG is a restrictive surgery technique. It consists of an almost entire resection of the stomach along the greater curvature and formation on a passage based on 
the lesser stomach curvature. The method is technically easier than RYGB and, simultaneously, leads to lesser nutritional deficiencies $[4,5]$. RYGB is a treatment combining the features of a restrictive and malabsorptive procedure. In this procedure a small pouch $(15-20 \mathrm{ml})$ is created in the upper part of the stomach. Next, a bypass is created between the stomach pouch and the intestine with a separate "Roux limb" $100-200 \mathrm{~cm}$ in length and an intestine-intestine bypass of enzymatic intestinal loop is formed $50-100 \mathrm{~cm}$ in length with alimentary limb $70-100 \mathrm{~cm}$ from the ligament of Treitz. The effect of the procedure is the limitation of the quantity of consumed food and, due to bypassing the lower part of the stomach, duodenum and initial part of jejunum - reduction of digestion and absorption of consumed food [6-8]. The patients are qualified for bariatric procedures according to the recommendations of the National Institutes of Health (NIH) [9]. The indications for bariatric procedure in case of people aged between 18 and 60 are: body mass index $(\mathrm{BMI}) \geq 40 \mathrm{~kg} / \mathrm{m}^{2}$ or $\geq 35 \mathrm{~kg} / \mathrm{m}^{2}$ for people with accompanying diseases (e.g. type 2 diabetes, cardiovascular diseases), and unsuccessful or short-lasting conservatory obesity treatment [10]. Surgical methods of obesity treatment include many and various techniques and it is difficult to assign explicit criteria which would allow to qualify patients to a particular type of procedure $[11,12]$.

\section{AIM OF THE STUDY}

Bariatric surgery is becoming an increasingly common way of treating morbid obesity globally. There are medical indications and contraindications based on which the patients are qualified for the procedures. The aim of the study was to determine and to compare the profiles of a patients treated with SG and RYGB bariatric surgery. The determination of patient's profile involved anthropometric and biochemical measurements and the assessment of diets.

It was assumed that between the patients qualified for two different types of procedures there are significant differences in biochemical parameters. Such assumption was made because the two methods are connected with different mechanisms reducing the digestion and absorption of nutrients.

\section{MATERIAL AND METHODS STUDY DESIGN}

The study received the acceptance of the Bioethical Commission at Pomeranian Medical University in Szczecin. Qualification for bariatric procedure (according to NIH criteria) was performed at the Independent Public Province Complex Hospital in SzczecinZdunowo. The study involved 60 patients (30 women and 30 men), among whom 33 people (20 women and 13 men) were qualified for RYGB, and 27 ( 10 women and 17 men) to SG procedure (Fig. 1). The data was collected
1-3 months before the surgery. The majority of patients (57\%) lived in large cities, had secondary education (52\%) and worked full time (55\%). As much as $78 \%$ of examined patients confirmed that they did not undertake any physical activity and led a sedentary lifestyle.

\section{STUDY GROUP CHARACTERISTIC}

The measurements of body mass, height, waist and hip circumferences were performed with the accuracy of $0.1 \mathrm{~kg}$ or $0.5 \mathrm{~cm}$.

Characterization of patients qualified for RYGB and SG are presented in Table 1 .

\section{QUESTIONNAIRE}

A standardized Food Frequency Questionnaire supplemented by a survey which contained questions on previous attempts to lose weight and their results (including yo-yo effect) were administered.

\section{BIOCHEMICAL ANALYSES}

Blood for the analyses was collected on fasting in the Independent Public Province Complex Hospital in Szczecin-Zdunowo. The following analyses were performed using calorimetric method: lipid profile, liver profile, glucose, glycated haemoglobin (HbAlc) and C-reactive protein (CRP) (Cobas Integra 400 plus).

\section{STATISTICAL ANALYSIS}

Obtained results were statistically analysed using STATISTICA 12 (Statsoft, Tulsa, Oklahoma, USA). A post hoc power analysis was performer using $G$ power software. The power of tests which showed statistical significance was above the recommended level of 0.8 . The normality of the distribution was tested using the

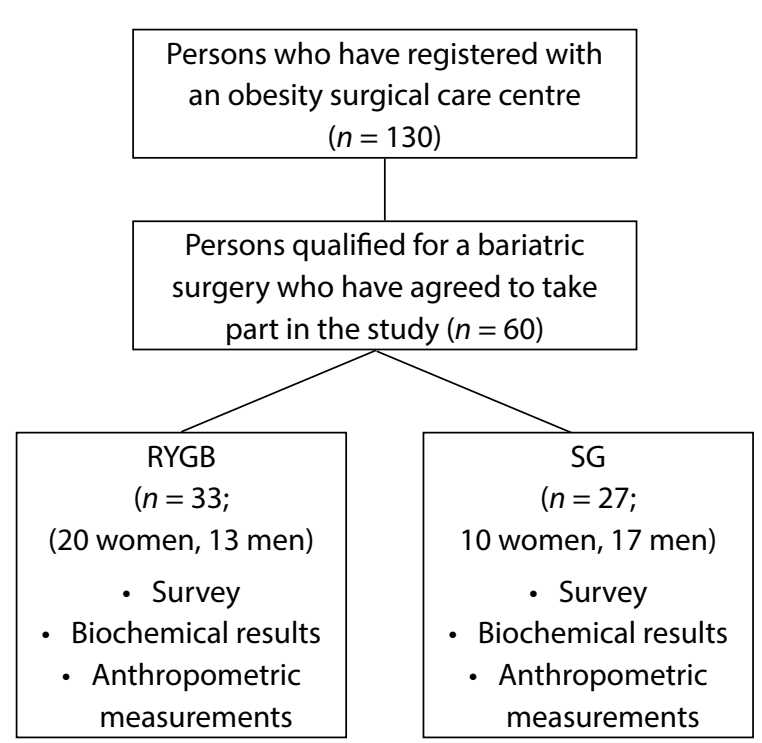

FIG. 1. Study flowchart 
TABLE 1. Anthropometric data for female and male group

\begin{tabular}{|c|c|c|c|c|c|c|c|c|}
\hline Feature & $n$ & $\begin{array}{c}\text { Age } \\
\text { (years) }\end{array}$ & $\begin{array}{l}\text { Body } \\
\text { mass } \\
(\mathrm{kg})\end{array}$ & $\begin{array}{l}\text { Height } \\
\text { (cm) }\end{array}$ & $\begin{array}{l}\text { Waist } \\
\text { circumference } \\
(\mathrm{cm})\end{array}$ & $\begin{array}{l}\text { Hip } \\
\text { circumference } \\
\text { (cm) }\end{array}$ & $\begin{array}{c}\text { BMI } \\
\left(\mathrm{kg} / \mathrm{m}^{2}\right)\end{array}$ & WHR \\
\hline \multicolumn{9}{|c|}{ Female group } \\
\hline RYGB & 20 & $44.8 \pm 12.2$ & $132.1 \pm 18.4$ & $168.6 \pm 6.8$ & $137.1 \pm 16$ & $142.7 \pm 13.3$ & $46.5 \pm 6.2$ & $1 \pm 0.1$ \\
\hline SG & 10 & $50.3 \pm 10.8$ & $134.5 \pm 21$ & $166.5 \pm 5$ & $146.6 \pm 12.3$ & $147.2 \pm 17.8$ & $48.5 \pm 6.7$ & $1 \pm 0.04$ \\
\hline $\begin{array}{l}\text { Statistica } \\
\text { analysis }\end{array}$ & & NS & NS & NS & NS & NS & NS & NS \\
\hline \multicolumn{9}{|c|}{ Male group } \\
\hline RYGB & 13 & $47.7 \pm 10$ & $140.3 \pm 24.7$ & $180.2 \pm 5.2$ & $141.6 \pm 13.8$ & $130.2 \pm 10.9$ & $43.1 \pm 6.6$ & $1.1 \pm 0.1$ \\
\hline SG & 17 & $47.2 \pm 9.9$ & $149.6 \pm 25.9$ & $179 \pm 10$ & $144.3 \pm 13.6$ & $133.3 \pm 10$ & $46.9 \pm 6.9$ & $1.1 \pm 0.07$ \\
\hline \multicolumn{2}{|c|}{$\begin{array}{l}\text { Statistical } \\
\text { analysis }\end{array}$} & NS & NS & NS & NS & NS & NS & NS \\
\hline
\end{tabular}

$B M I$ - body mass index, RYGB - Roux-en-Y gastric bypass, SG - sleeve gastrectomy, NS - statistically insignificant

Shapiro-Wilk test. Independent samples $t$-test was used with respect to a variable. The level of statistical significance was $p \leq 0.05$.

\section{RESULTS}

\section{BIOCHEMICAL RESULTS IN FEMALE GROUP}

Significantly higher values of CRP were noted among women qualified to SG $(0.79 \pm 0.31 \mathrm{mg} / \mathrm{l} \mathrm{SG}$ vs 0.47 $\pm 0.22 \mathrm{mg} / \mathrm{l} \mathrm{RYGB}$ ). In the group of women qualified for SG significantly higher values of alanine aminotransferase ( $37.14 \pm 10.07 \mathrm{U} / 1 \mathrm{SG}$ vs $24.44 \pm 7.29 \mathrm{U} / \mathrm{l} \mathrm{RYGB})$ and asparagine aminotransferase $(28.25 \pm 10.6 \mathrm{U} / \mathrm{l} \mathrm{SG}$ vs $21.61 \pm 5.6 \mathrm{U} / \mathrm{l}$ RYGB) were noted. Lipid profiles in both groups of female patients deviated from normal. There was significantly higher level of total cholesterol among women qualified to SG $(235.7 \pm 33.05 \mathrm{mg} / \mathrm{dl}$ SG vs 203.83 $\pm 29.22 \mathrm{md} / \mathrm{dl}$ RYGB). The level of glucose on fasting in both groups of female patients indicated improper gly- caemia on fasting, reaching significantly higher values in women qualified to SG $(112.64 \pm 17.94 \mathrm{mg} / \mathrm{dl} \mathrm{SG}$ vs $100.28 \pm 10.08 \mathrm{mg} / \mathrm{dl}$ RYGB). The level of HbAlc was also significantly higher in women treated with SG (6.06 $\pm 0.67 \%$ SG vs $5.53 \pm 0.59 \%$ RYGB) (Table 2).

\section{BIOCHEMICAL RESULTS IN MALE GROUP}

The level of CRP was slightly higher in people qualified to RYGB $(0.52 \pm 0.29 \mathrm{mg} / \mathrm{l}$ RYGB vs $0.49 \pm 0.33 \mathrm{mg} / \mathrm{l}$ SG). The level of alanine aminotransferase (ALT) was elevated in both groups of male patients, but higher values were noted for men qualified for SG $(47.21 \pm 45.85$ U/l SG vs $45 \pm 33.69 \mathrm{U} / \mathrm{l} \mathrm{RYGB})$. The concentration of $\gamma$-glutamyl transpeptidase (GGTP) was significantly higher in people qualified to RYGB (55.75 $\pm 27.71 \mathrm{U} / 1 \mathrm{RYGB}$ vs $28.4 \pm 11.36$ $\mathrm{U} / \mathrm{l} \mathrm{SG}$ ). The levels of LDL (116.94 $\pm 45.16 \mathrm{mg} / \mathrm{dl}$ RYGB vs $104.47 \pm 24.47 \mathrm{mg} / \mathrm{dl} \mathrm{SG})$ and TG (185.54 $\pm 87.13 \mathrm{mg} / \mathrm{dl}$ RYGB vs $164.66 \pm 137.5 \mathrm{mg} / \mathrm{dl} \mathrm{SG}$ ) were elevated in men

TABLE 2. Biochemical parameters and methods of losing weight tried by the patients

\begin{tabular}{|c|c|c|c|c|c|c|c|}
\hline \multirow[t]{2}{*}{ Parameter } & \multirow[t]{2}{*}{ Unit } & RYGB & SG & $p$ & RYGB & SG & $p$ \\
\hline & & \multicolumn{3}{|c|}{ Female group } & \multicolumn{3}{|c|}{ Male group } \\
\hline CRP & $\mathrm{mg} / \mathrm{l}$ & $0.47( \pm 0.22)$ & $0.79( \pm 0.31)$ & 0.016 & $0.52( \pm 0.29)$ & $0.49( \pm 0.33)$ & NS \\
\hline ALT & $\mathrm{U} / \mathrm{I}$ & $24.44( \pm 7.29)$ & $37.14( \pm 10.7)$ & 0.002 & $45.0( \pm 33.69)$ & $47.21( \pm 45.85)$ & NS \\
\hline AST & $\mathrm{U} / \mathrm{I}$ & $21.61( \pm 5.6)$ & $28.25( \pm 10.57)$ & 0.045 & $31.58( \pm 21.77)$ & $28.93( \pm 15.7)$ & NS \\
\hline GGTP & $\mathrm{U} / \mathrm{I}$ & $25.5( \pm 10.35)$ & $25.86( \pm 10.25)$ & NS & $55.75( \pm 27.71)$ & $28.40( \pm 11.35)$ & 0.012 \\
\hline Triglycerides & $\mathrm{mg} / \mathrm{dl}$ & $150.15( \pm 113.61)$ & $148.06( \pm 41.66)$ & NS & $185.54( \pm 87.13)$ & $164.66( \pm 137.5)$ & NS \\
\hline Total cholesterol & $\mathrm{mg} / \mathrm{dl}$ & $203.83( \pm 29.22)$ & $235.7( \pm 33.05)$ & 0.021 & $191.69( \pm 43.55)$ & $184.21( \pm 27.97)$ & NS \\
\hline HDL & $\mathrm{mg} / \mathrm{dl}$ & $52.77( \pm 13.71)$ & $53.44( \pm 12.16)$ & NS & $46.38( \pm 14.47)$ & $46.29( \pm 17.3)$ & NS \\
\hline LDL & $\mathrm{mg} / \mathrm{dl}$ & $129.07( \pm 36.13)$ & $143.56( \pm 38.79)$ & NS & $116.94( \pm 45.16)$ & $104.47( \pm 24.47)$ & NS \\
\hline Glucose on fasting & $\mathrm{mg} / \mathrm{dl}$ & $100.28( \pm 10.08)$ & $112.64( \pm 17.94)$ & 0.035 & $132.73( \pm 53.02)$ & $107.45( \pm 21.53)$ & NS \\
\hline $\mathrm{HbA1c}$ & $\%$ & $5.53( \pm 0.59)$ & $6.06( \pm 0.67)$ & 0.045 & $6.28( \pm 1.23)$ & $5.90( \pm 0.64)$ & NS \\
\hline
\end{tabular}

RYGB - Roux-en-Y gastric bypass, SG - sleeve gastrectomy, CRP-C-reactive protein, ALT-alanine aminotransferase, AST-aspartate aminotransferase, GGTP- $\gamma$-glutamyl transpeptidase, HDL - high density lipoprotein, LDL - low density lipoprotein, HbA1c-glycated haemoglobin, NS - statistically insignificant 
qualified to both types of procedures but higher values were observed for people qualifies for RYGB. The same relation was noted in case of the level of glucose on fasting, which in the group of male patients qualified for SG showed improper glycaemia on fasting (107.45 $\pm 21.53 \mathrm{mg} / \mathrm{dl}$ ), and in patients qualified for RYGB indicated diabetes $(132.73 \pm 53.02 \mathrm{mg} / \mathrm{dl})$ (Table 2$)$.

\section{HEALTH CONDITION IN FEMALE GROUP}

Hypertension was recognized in $40 \%$ of female patients qualified for RYGB, type 2 in 35\%, and hypothyroidism in $30 \%$. Additionally, the following diseases were recognized among women: the diseases of respiratory system (asthma and chronic obstructive pulmonary disease [COPD]), Hashimoto's thyroiditis, H. pylori infection, gastroesophageal reflux disease and psoriasis. Interestingly, $30 \%$ of female candidates to RYGB procedure declared they do not suffer from any chronic disease. Chronic diseases were also noted in case of patients qualified for SG. Hypertension was recognised in $60 \%$ of women, hypothyroidism in $30 \%$ and type 2 diabetes in $20 \%$ of them. Respiratory diseases (asthma, COPD), rheumatoid arthritis and anxiety disorders were also observed in these female patients. $20 \%$ of women declared no chronic diseases.

\section{HEALTH CONDITION IN MALE GROUP}

The diseases accompanying obesity were reported in case of all men who were candidates for RYGB. More than $92 \%$ of male patients suffered from hypertension, and more than $46 \%$ were diagnosed with type 2 diabetes. Hypothyroidism, gout and depression occurred in more than $15 \%$ of the patients. The following diseases were also reported in male participants: atherosclerosis, anxiety and gastroesophageal reflux disease. Among male patients who were candidates for SG more than 94\% suffered from hypertension and more than $46 \%$ had type 2 diabetes. Only $5.9 \%$ of patients did not declare any chronic diseases.

The prevalence of chronic diseases among patients qualified for RYGB and SG are presented in Figures 2 and 3.

\section{ATTEMPTS TO LOSE WEIGHT IN FEMALE GROUP}

All female patients qualified for both types of procedures had a history of numerous and unsuccessful attempts to lose weight. Majority of female patients declared that they used diets described as low-energy diets, with energy supply of 800-1200 kcal in case of women qualified to RYGB and 800-1200 and 1200$1500 \mathrm{kcal}$ in case of women qualified for SG. Additionally, $15 \%$ of women qualified for RYGB previously underwent surgical procedure to lose weight including a balloon and a gastric band. Fifteen percent of women qualified for RYGB and $10 \%$ of women qualified for SG tried to lose body weight using over-the-counter dietary supplements supporting weight loss without limiting the energy intake of consumed meals. Most female patients (85\% RYGB vs $100 \%$ SG) admitted that each time their attempts to lose weight were followed by a yo-yo effect, which, on average, resulted in $18.8 \mathrm{~kg}( \pm 17.12)$ weight gain in candidates for RYGB and $16.4 \mathrm{~kg}( \pm 11.6)$ among candidates to SG (Table 3).

\section{ATTEMPTS TO LOSE WEIGHT IN MALE GROUP}

Men qualified for surgical obesity treatment declared that they had a history of several attempts to lose weight. Most common strategy for them was to use low-energy diet, with energy supply in most cases $800-1200 \mathrm{kcal}$ in case of candidates for RYGB and 1200-1500 kcal in case of candidates for SG. Most men (62\% RYGB vs 65\% SG) admitted that their attempts to lose weight were followed by a yo-yo effect, which, on average, resulted in $17.63 \mathrm{~kg}$ $( \pm 10.09)$ weight gain in group of men qualified for RYGB and $23.33 \mathrm{~kg}( \pm 16.77)$ in group of those qualified for SG (Table 3).

\section{DISCUSSION}

In this study android-type obesity was observed in all the patients, however higher values of waist circumference and BMI were noted among patients qualified for SG. Similar relation regarding waist-to-hip ration (WHR) was observed only in female group. Higher values of waist-to-hip ratio (WHR) were noted in male than female group. In the study of Sjöström et al. abdominal obesity was also reported in all the patients qualified for surgical obesity treatment [13]. Android-type obesity is one of the factors increasing the risk of metabolic syndrome development. This syndrome is characterized by the coexistence of atherosclerosis risk factors based on insulin resistance, which is connected with the risk of developing cardiovascular diseases and type 2 diabetes. Moreover, the syndrome is linked to systemic inflammatory state and non-alcoholic liver disease [14]. Besides observed android-type obesity and often metabolic syndrome, regardless of the sex, the results of biochemical analyses of blood of patients qualified for both procedures showed significant abnormalities. Among female patients qualified for SG there were higher parameters indicating the presence of: inflammatory state (CRP), dyslipidaemia (total cholesterol, LDL), improper glycaemia (glucose on fasting, $\mathrm{HbAlc}$ ), and higher values for parameters referring to liver function (ALT and AST) than in women qualified for RYGB. Similar results were obtained in other studies [15]. The results of biochemical analyses of blood from patients qualified for bariatric surgery deviated from normal. Such abnormalities together with sedentary lifestyle and smoking facilitate the development of type 2 diabetes and cardiovascular diseases, including coronary artery disease with its most serious consequences such as heart attack and stroke $[16,17]$.

One of the NIH criteria qualifying patients to bariatric surgery is a history of previous unsuccessful 


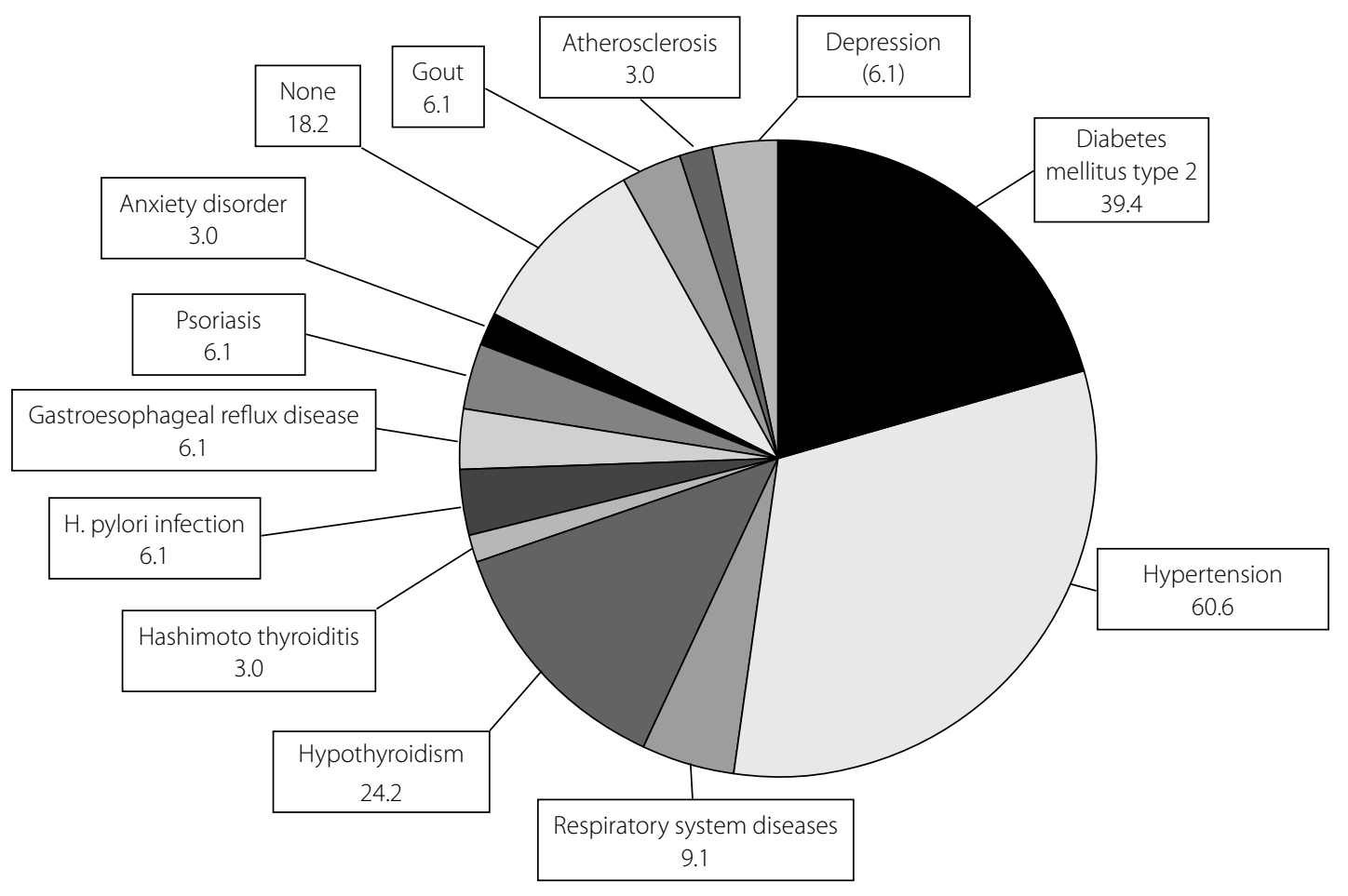

FIG. 2. Prevalence of chronic diseases among patients qualified for Roux-en-Y gastric bypass (\%)

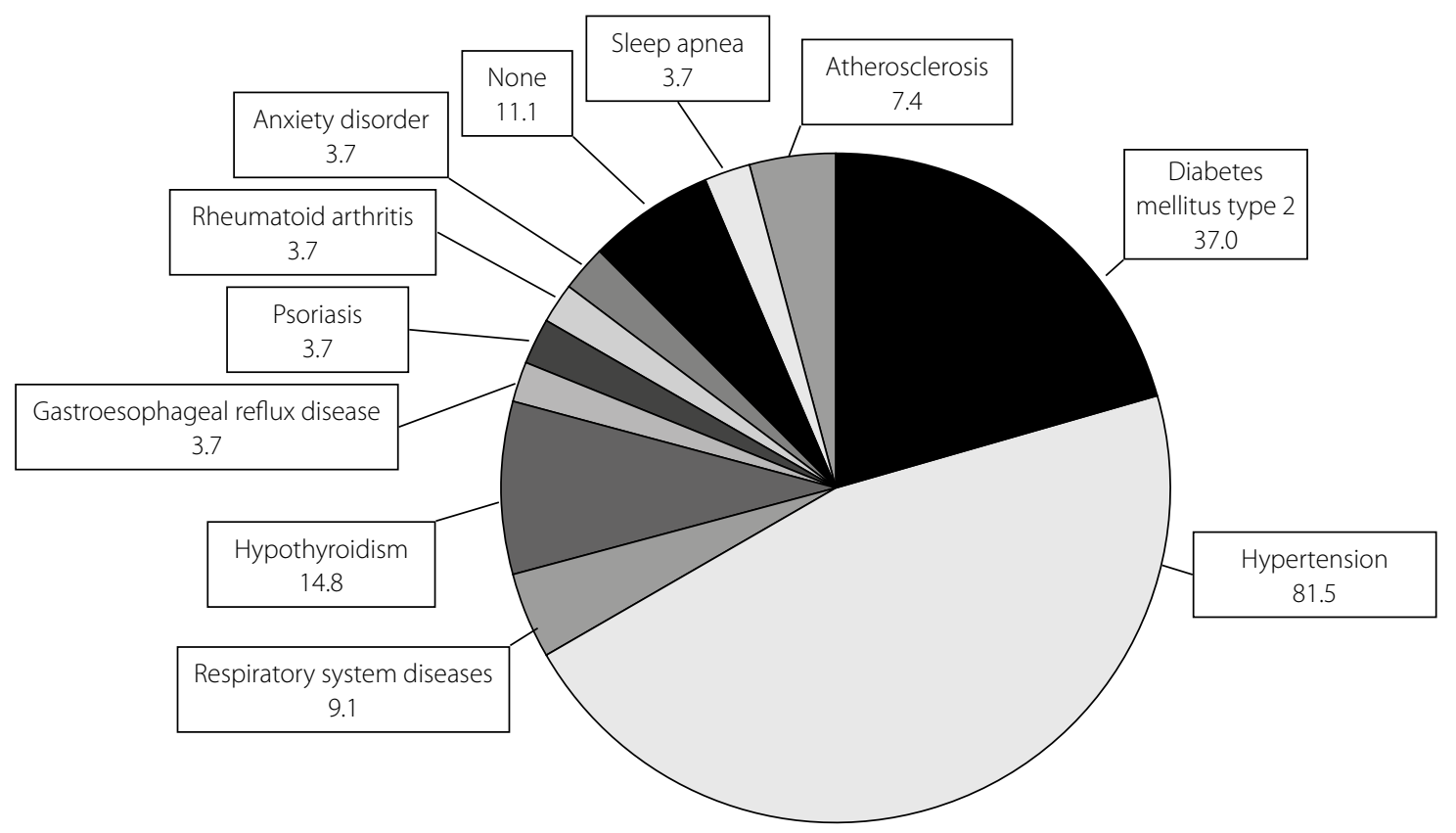

FIG. 3. Prevalence of chronic diseases among patients qualified for sleeve gastrectomy (\%)

attempts at losing weight. Body mass reduction affects the improvement of metabolic parameters and is the basis for prevention and treatment of high blood pressure, atherosclerosis, diabetes, dyslipidaemia and some types of cancer [18]. Unfortunately, often the attempts to lose weight made by patients on their own (without the control of a dietician and/or a doctor) are based on using "miracle" diets promoted by the media. Such diets are not scientifically justified, are imbalanced, one-sided, often of very low caloric value and lead to the development of improper dietary habits. The patients on such diets in fact experience substantial weight loss, but it results mainly from significant loss of fat free body mass and water. These diets for longer period of time become unacceptable for a patient, who usually returns to former dietary habits and even increases the consumption as 
TABLE 3. Methods of losing weight tried by the patients (\%)

\begin{tabular}{|c|c|c|c|c|c|c|}
\hline \multirow[t]{2}{*}{ Method } & RYGB & SG & $p$ & RYGB & SG & $p$ \\
\hline & \multicolumn{3}{|c|}{ Female group } & \multicolumn{3}{|c|}{ Male group } \\
\hline \multicolumn{7}{|l|}{ Attempts to lose weight } \\
\hline High-protein diet & 30 & 30 & NS & 15.4 & 23.5 & NS \\
\hline Low-energy diet & 70 & 50 & NS & 53.9 & 53 & NS \\
\hline Low-fat diet & 5 & 30 & NS & 15.4 & 5.9 & NS \\
\hline Vegetable and fruit diet & 15 & 0 & NS & 0 & 5.9 & NS \\
\hline Diet supplements supporting weight loss & 15 & 10 & NS & 7.7 & 0 & NS \\
\hline Bariatric surgery (stomach balloon band) & 15 & 0 & NS & 7.7 & 5.9 & NS \\
\hline Consultation with a dietician & 5 & 0 & NS & 0 & 11.8 & NS \\
\hline \multicolumn{7}{|l|}{ Caloric load of used diets (kcal) } \\
\hline Starvation & 0 & 0 & NS & 0 & 5.9 & NS \\
\hline $500-800$ & 15 & 10 & NS & 0 & 0 & NS \\
\hline $800-1200$ & 50 & 40 & NS & 53.9 & 23.5 & 0.041 \\
\hline $1200-1500$ & 30 & 40 & NS & 7.7 & 41.2 & NS \\
\hline $1500-1800$ & 0 & 0 & NS & 15.4 & 17.7 & NS \\
\hline$>2000$ & 0 & 0 & NS & 23.1 & 11.8 & NS \\
\hline $\begin{array}{l}\text { Supplementation without caloric } \\
\text { restrictions }\end{array}$ & 5 & 10 & NS & 0 & 0 & NS \\
\hline
\end{tabular}

RYGB - Roux-en-Y gastric bypass, SG - sleeve gastrectomy, NS - statistically insignificant

a compensation for the period of self-denial. The result of such diets is decreased basal metabolic rate (BMR), which with simultaneously increased level of consumption leads to the situation when an organism quickly renews the deficiencies in nutrients and water, resulting in regained body weight. Additionally, such diets after longer use deepen the deficiencies in vitamins and minerals and enhance the diseases accompanying obesity hypertriglyceridemia and liver and kidneys failure [19]. In this study, patients on average had a history of numerous $(\geq 6)$ attempts to lose body weight. The most commonly used diets were low-energy diets with energy supply below basal metabolic rate (BMR). Such diets usually lead to quick body mass reduction but at the same time pose a high risk of malnutrition and deficiencies in vitamins, minerals, polyunsaturated fatty acids, antioxidants, as well as protein loss and electrolyte imbalance. Malnourished patient becomes weakened both physically (e.g. loss of muscle mass and strength, decreased immunity, osteoporosis, endocrine disorders) and psychologically (e.g. depression) which is often manifested by discouragement to continue the diet, not adhering to dietary recommendations and yo-yo effect $[20,21]$.

In this study the majority patients of both sexes declared that their past diets below BMR resulted in a yo-yo effect. Even though malnutrition is not immediately visible it can be health-threatening. Starvation leads to metabolic acidosis, which reduces hunger but simultaneously results in the damage to internal organs due to exploitation of endogenous resources, water and electrolytes imbalance and protein deficiencies. Due to deficient protein intake with the diet its internal resources are depleted, which is connected to reduction in metabolic rate. Such process creates a vicious cycle and because of the yo-yo effect the patient starts another imbalanced diet. In this study, $30 \%$ of female candidates for both procedures, $15 \%$ of men qualified for RYGB and $24 \%$ of men qualified for SG admitted that they tried to lose weight using a high-protein diet. In the study of Szczuko et al., the authors showed that using a highprotein Dukan diet may be very harmful, especially in the first phase of the diet, which eliminates carbohydrate products entirely [22]. Such diet does not allow to supply the demand of brain cells on glucose. Body mass reduction on Dukan diet is connected to total calories limitation, increased satiety due to the development of ketosis formed as an effect of glucose deficiency, but also to dehydration, which occurs due to the release of glycogen from muscles and liver (the loss of $400 \mathrm{~g}$ of glycogen is related to the loss of $1 \mathrm{~kg}$ of water) [23,24]. Additionally, each of the phases of this diet increases the risk of cardiovascular diseases as a result of high consumption of saturated fatty acids and cholesterol, with simultaneous low consumption of folates, which regulate the concentration of homocysteine in blood [22]. Excessive amount of protein in the diet leads to increased filtration in kidneys, positive nitrogen balance, increased production of urea, ammonia and uric acid, which increases the risk of kidneys and liver overload. Moreover, disruption of acid-base homeostasis and significant loss of calcium from bones, due to high 
consumption of protein, predispose to the development of osteoporosis [25]. High-protein diet also increases the risk of erythropoiesis malfunction due to low consumption of iron, folates, zinc and copper, which can be the cause of lowered level of haemoglobin and reduced number of correctly formed erythrocytes [22]. Moreover, in this study men who were qualified for RYGB had significantly higher levels of GGTP than men qualified for SG, which can be a factor predisposing for cholestasis. As reported by Fica and Sirbu [26], RYGB is related to a $40 \%$ risk of cholelithiasis. Cholestasis may be caused by both preoperative conditions of patients - obesity and nutritional errors (small number of meals and insufficient intake of dietary fibre - which adversely affect the process of gall bladder contraction and lead to deficiencies in unsaturated fatty acids, which in turn results in decreased amount of lecithin in bile) and quick body weight loss after the operation. Some studies report also the potential effect of intestinal microflora on gall stones formation. Increased number of Proteobacteria after RYGB [27, 28] is linked to higher incidence of gall stones [29] among the patients subjected to surgical obesity treatment.

Significant divergence was observed in this study with respect to the qualification of the patients to particular types of procedures. Twice as many women were qualified to RYGB, whereas more men were qualified to SG. Sleeve gastrectomy is simpler and easier to perform procedure in comparison with RYGB [30]. In case of obese and extremely obese (BMI > 50) patients it allows for the reduction of body weight with simultaneously few perioperative complications. As a singular surgical procedure, it helps regain control over the parameters of dyslipidaemia and metabolic syndrome and also leads to significant improvement in glucose level, and even to remission of diabetes in most of the population [31]. Based on that it could be assumed that majority of examined men were qualified for SG because they were characterised by significantly higher body weight $(149.64 \mathrm{~kg})$ and longer waist circumference $(144.31 \mathrm{~cm})$ that patients qualified for RYGB (body mass - $140.3 \mathrm{~kg}$; waist circumference $-141.62 \mathrm{~cm}$ ). Such body mass in men significantly increased the risk of perioperative complications, therefore the choice of the method, which is regarded as easy and quick to perform, seems to be justified. It can be regarded that based on the same criteria the majority of women were qualified for RYGB. These women were 5.6 years younger, had waist circumference shorter by $9.5 \mathrm{~cm}$ and hip circumference shorter by $4.5 \mathrm{~cm}$ and, in comparison with women qualified to SG, their BMI was lower (46.5 vs $48.45 \mathrm{~kg} / \mathrm{m} 2$ ), as well as WHR (0.96 vs 1.0). In the group of women qualified to RYGB a lower inflammatory state was observed, measured as the level of CRP, whose values were in this group significantly lower than in SG group (0.47 vs $0.79 \mathrm{mg} / \mathrm{l})$. The parameters mentioned above allow to characterize the patients qualified for RYGB as people at lower perioperative risk than women qualified to SG. Another factor which affected the qualification of most of women to RYGB could be more frequent prevalence of type 2 diabetes in this group of female patients (35\% RYGB vs $20 \%$ SG). In the study by Lee et al. during one year after bariatric surgery the remission of type 2 diabetes was proved for $93 \%$ of patients subjected to RYGB and for $47 \%$ of patients after SG [32]. On the other hand, in the study of Szczuko et al. no differences were noted after 12-month observation in such parameters as: body mass reduction, body weight, waist circumference and hip circumference, and BMI and WHR were at similar levels in both groups of patients [33]. However, the authors pointed out that after RYGB there was higher decrease of the levels of total cholesterol, LDL and triglycerides in comparison with SG, which together with very low concentration of HDL in blood was connected to liver overload. The authors showed that SG should be considered as first, because RYGB is a more invasive procedure, related to excessive overload of liver lasting for several months and lifelong limitation of nutrients absorption.

\section{CONCLUSIONS}

1. Patients at higher perioperative risk (due to anthropometric and biochemical parameters) were qualified for less invasive procedure (SG).

2. Higher risk of cholelithiasis development after the surgery would be attributed to irrational attempts of body weight loss before the procedure, and not to the RYGB itself.

3. Numerous attempts to lose weight using scientifically unapproved and unbalanced diets demonstrate the low level of nutritional knowledge and the need to educate the patients.

4. Undoubtedly, further research is needed to determine which patients will get the most health benefit from a particular type of surgery.

\section{DISCLOSURE}

The authors report no conflict of interest.

\section{References}

1. Caballero B. The global epidemic of obesity: an overview. Epidemiol Rev 2007; 29: 1-5.

2. James WP. The epidemiology of obesity: the size of the problem. J Intern Med 2008; 263 (4): 336-352.

3. Kizy S, Jahansouz C, Downey MC, et al. National trends in bariatric surgery 2012-2015: demographics, procedure selection, readmissions, and cost. Obes Surg 2017; 27 (11): 2933-2939.

4. Yang OO, Loi K, Liew V, et al. Staged laparoscopic sleeve gastrectomy followed by Roux-en-Y gastric bypass for morbidly obese patients: a risk reduction strategy. Obes Surg 2008; 18 (12): 1575-1580.

5. Paluszkiewicz R, Kalinowski P, Wróblewki T, et al. Prospective randomized clinical trial of laparoscopic sleeve gastrectomy versus open Roux-en-Y gastric bypass for the management of 
patients with morbid obesity. Wideochir Inne Tech Maloinwazyjne 2012; 7 (4): 225-232.

6. Kaska , Proczko M, Kobiela J. Dynamics of type 2 diabetes mellitus laboratory remission after Roux-en-Y gastric bypass in patients with body mass index lower than $25 \mathrm{~kg} / \mathrm{m}(2)$ and higher than $35 \mathrm{~kg} / \mathrm{m}(2)$ in a 3-year observation period. Wideochir Inne Tech Maloinwazyjne 2014; 9 (4): 523-530.

7. Celiker H. A new proposed mechanism of action for gastric bypass surgery: Air hypothesis. Med Hypotheses 2017; 107: 81-89.

8. Mulla CM, Middelbeek RJW, Patti ME. Mechanisms of weight loss and improved metabolism following bariatric surgery. Ann N Y Acad Sci 2018; 1411 (1): 53-64.

9. Hubbard VS, Hall WH. Gastrointestinal surgery for severe obesity. Obes Surg 1991; 1 (3): 257-265.

10. Mechanick JI, Youdim A, Jones DB, et al. Clinical Practice Guidelines for the Perioperative Nutritional, Metabolic, and Nonsurgical Support of the Bariatric Surgery Patient - 2013 Update: Cosponsored by American Association of Clinical Endocrinologists, The Obesity Society, and American Society for Metabolic \& Bariatric Surgery. Obesity (Silver Spring) 2013; 21 (Suppl 1): S1-S27.

11. Jastrzębska M, Ostrowska L. Zalecenia dietetyczne po zabiegach bariatrycznych [Dietary recommendations for bariatric surgery patients]. Forum Zaburzeń Metabolicznych 2010; 1 (4): 201-209.

12. JastrzębskaMierzyńska M, Ostrowska L, Wasiluk D, Konarzewska-Duchnowska E. Dietetic recommendations after bariatric procedures in the light of the new guidelines regarding metabolic and bariatric surgery. Rocz Panstw Zakl Hig 2015; 66 (1): 13-19.

13. Sjöström L, Peltonen M, Jacobson P, et al. Bariatric surgery and long-term cardiovascular events. JAMA 2012; 307 (1): 56-65.

14. Siemińska L. Tkanka tłuszczowa. Patofizjologia, rozmieszczenie, różnice płciowe oraz znaczenie w procesach zapalnych i nowotworowych [Adipose Tissue. Pathophysiology, Distribution, Sex Differences and the Role in Inflammation and Cancerogenesis]. Endokrynol Pol 2007; 58 (4): 330-342.

15. Gero D, Favre L, Allemann P, et al. Laparoscopic Roux-en-Y gastric bypass improves lipid profile and decreases cardiovascular risk: a 5-year longitudinal cohort study of 1048 patients. Obes Surg 2018; 28 (3): 805-811.

16. Włodarczyk A, Strojek K. Glucose intolerance, insulin resistance and metabolic syndrome in patients with stable angina pectoris. Obesity predicts coronary atherosclerosis and dysglycemia. Pol Arch Med Wewn 2008; 118 (12): 719-726.

17. Niewada M, Członkowska A. Prevention of ischemic stroke in clinical practice: a role of internists and general practitioners. Pol Arch Med Wewn 2014; 124 (10): 540-548.

18. Zhang N, Maffei A, Cerabona T, et al. Reduction in obesityrelated comorbidities: is gastric bypass better than sleeve gastrectomy? Surg Endosc 2013; 27 (4): 1273-1280.

19. Ostrowska L. Leczenie dietetyczne otyłości - wskazówki dla lekarzy praktyków [Dietetical obesity treatment - tips for clinicians]. Forum Zaburzeń Metabolicznych 2010; 1 (1): 22-30.

20. Farioli Vecchioli S, Sacchetti S, di Robilant VN, et al. The role of physical exercise and omega-3 fatty acids in depressive illness in the elderly. Curr Neuropharmacol 2018; 16 (3): 308-326.
21. Li S, Gao X, Wei Y, et al. The relationship between iron deficiency and thyroid function in Chinese women during early pregnancy. J Nutr Sci Vitaminol (Tokyo) 2016; 62 (6): 397-401.

22. Szczuko M, Pieszak N, Jamioł-Milc D, Stachowska E. Dieta proteinowa $\mathrm{w}$ świetle zasad racjonalnego żywienia. Analiza składu jadłospisów [Protein-based diet with respect to the principles of rational nutrition. Menus analysis]. Pomeranian J Life Sci 2016; 62 (2): 31-38.

23. Łagowska K, Woźniewicz M, Jeszka J. Ocena wartości odżywczej diet odchudzających zamieszczonych na portalach internetowych [Estimation of nutritional value of hypocaloric diets published on Internet portals]. Probl Hig Epidemiol 2011; 92 (4): 824-827.

24. Wyka J, Malczyk E, Misiarz M, et al. Assessment of food intakes for women adopting the high protein Dukan diet. Rocz Panstw Zakl Hig 2015; 66 (2): 137-142.

25. Kłosiewicz-Latoszek L, Szostak WB. Kontrowersje wokół diet odchudzających [Controversy concerning weight reducing diets]. Post Nauk Med 2011; XXIV (9): 790-794.

26. Fica S, Sirbu A. Metabolic surgery for diabetes mellitus between benefits and risks. Acta Endocrinologica 2015; XI (2): 212-219.

27. Graessler J, Qin Y, Zhong H, et al. Metagenomic sequencing of the human gut microbiome before and after bariatric surgery in obese patients with type 2 diabetes: correlation with inflammatory and metabolic parameters. Pharmacogenomics J 2013; 13 (6): 514-522.

28. Li JV, Reshat R, Wu Q, et al. Experimental bariatric surgery in rats generates a cytotoxic chemical environment in the gut contents. Front Microbiol 2011; 2: 183.

29. Wu T, Zhang Z, Liu B, et al. Gut microbiota dysbiosis and bacterial community assembly associated with cholesterol gallstones in large-scale study. BMC Genomics 2013; 14: 669.

30. Barzin M, Khalaj A, Motamedi MA, et al. Safety and effectiveness of sleeve gastrectomy versus gastric bypass: one-year result of Tehran Obesity Treatment Study (TOTS). Gastroenterol Hepatol Bed Bench 2016; 9 (Suppl 1): S62-S69.

31. Sethi P, Thillai M, Nain PS, et al. Effects of laparoscopic sleeve gastrectomy on central obesity and metabolic syndrome in Indian adults - a prospective study. J Clin Diagn Res 2017; 11 (1): PC01-PC04.

32. Lee W-J, Chong K, Ser K-H, et al. Gastric Bypass vs Sleeve Gastrectomy for Type 2 Diabetes Mellitus. A randomized controlled trial. Arch Surg 2011; 146 (2): 143-148.

33. Szczuko M, Komorniak N, Hoffmann M, et al. Body weight reduction and biochemical parameters of the patients after RYGB and SG bariatric procedures in 12-month observation. Obes Surg 2017; 27 (4): 940-947.

\section{AUTHORS' CONTRIBUTIONS}

NK, MS, MH and BK prepared a research concept of the publication. $\mathrm{NK}, \mathrm{MH}$ and BK collected data and NK, MS and KK analysed them. NK wrote the first version of the article. NK, MS critically revised it. NK, MS and KK finally approved the publication. 